\title{
Trigeminal trophic syndrome associated with post-herpetic neuralgia - report of a rare case with review of literature
}

\section{Zespół troficzny nerwu trójdzielnego związany z neuralgią po przebytym półpaścu - opis rzadkiego przypadku i przegląd piśmiennictwa}

\author{
Pallvi Kaul', Sabha Mushtaq², Parmod Kalsotra ${ }^{3}$ \\ 'Department of Otolaryngology and Head Neck Surgery, Patel Hospital, Jalandhar, Punjab, India \\ 2Department of Dermatology, Venereology and Leprology, SMGS Hospital, Government Medical College, Jammu, Jammu and Kashmir, \\ India \\ ${ }^{3}$ Department of Otolaryngology and Head Neck Surgery, SMGS Hospital, Government Medical College, Jammu, Jammu and Kashmir, \\ India \\ 'Oddział Otolaryngologii i Chirurgii Głowy i Szyi, Szpital Patel, Jalandhar, Punjab, Indie \\ 2Zakład Dermatologii, Wenerologii i Trądu, Szpital SMGS, Rządowy Wydział Lekarski, Jammu, Jammu i Kaszmir, Indie \\ ${ }^{3}$ Oddział Otolaryngologii i Chirurgii Głowy i Szyi, Szpital SMGS, Rządowy Wydział Lekarski, Jammu, Jammu i Kaszmir, Indie
}

Dermatol Rev/Przegl Dermatol 2018, 105, 542-547 DOI: https://doi.org/I0.5। |4/dr.2018.78075

\author{
CORRESPONDING AUTHOR/ \\ ADRES DO KORESPONDENCJI: \\ Dr. Sabha Mushtaq \\ Department of Dermatology, \\ Venereology \\ and Leprology \\ SMGS Hospital \\ Government Medical College \\ 180001 Jammu \\ Jammu and Kashmir, India \\ Phone: +91 9796444136 \\ E-mail: smqazi.gmc@gmail.com
}

\begin{abstract}
Introduction. Trigeminal trophic syndrome is a rare clinical entity characterized by a triad of ala nasi ulceration, trigeminal anaesthesia and paraesthesia.

Objective. To report a patient with painless facial and scalp ulceration which was diagnosed as trigeminal trophic syndrome following herpes zoster.

Case report. A 72-year-old man, who had suffered from herpes zoster in the trigeminal nerve distribution 6 months prior, presented with a 3-month history of unilateral facial and scalp ulceration in the same distribution. Diagnosis of trigeminal trophic syndrome was reached after excluding infectious, malignant and granulomatous conditions.

Conclusions. Post-herpetic trigeminal trophic syndrome has been scarcely reported. Reports on this rare entity can be found both in dermatological and otolaryngology literature due to overlapping nature of the condition which makes it important for both these specialities. We are reporting this case due to the paucity in world literature and to apprise the clinicians about this unusual condition to reduce the risk of misdiagnosis.
\end{abstract}

\section{STRESZCZENIE}

Wprowadzenie. Zespół troficzny nerwu trójdzielnego to rzadka jednostka chorobowa charakteryzująca się trzema objawami: owrzodzeniem skrzydełek nosa, znieczuleniem nerwu trójdzielnego i parestezją.

Cel pracy. Opis przypadku pacjenta $z$ niebolesnym owrzodzeniem twarzy i skóry głowy, które zdiagnozowano jako zespół troficzny nerwu trójdzielnego po przebytym półpaścu.

Opis przypadku. Mężczyzna 72-letni zgłosił się 6 miesięcy po przebyciu półpaśca nerwu trójdzielnego. Klinicznie stwierdzono jednostronne 
owrzodzenie twarzy i skóry głowy, które wystąpiło w tym samym miejscu 3 miesiące później. Po wykluczeniu chorób zakaźnych, nowotworowych i ziarniniakowych rozpoznano zespół troficzny nerwu trójdzielnego.

Wnioski. Zespół troficzny nerwu trójdzielnego po przebytym półpaścu jest rzadko opisywany. Doniesienia o tej chorobie znajdują się w piśmiennictwie dermatologicznym i otolaryngologicznym, ponieważ ze względu na swój charakter jest ona ważna dla obu specjalności. Znajomość choroby jest istotna, by uniknąć błędnego rozpoznania w takich przypadkach.

Key words: trigeminal trophic syndrome, gasserian ganglion, herpes zoster, trigeminal nerve.

Słowa kluczowe: zespół troficzny nerwu trójdzielnego, zwój trójdzielny, półpasiec, nerw trójdzielny.

\section{INTRODUCTION}

The first description of trigeminal trophic syndrome dates back to 1901 when German neurologist Wallenberg [1] described ala nasi erosion following Wallenberg syndrome until its first mention in English language literature by Lovemen [2] and Mckenzie [3] independently in 1933. Trigeminal trophic syndrome was previously known as ulceration en arc because of the typical crescentic involvement of the ala nasi.

Trigeminal trophic syndrome is an uncommon condition that may occur subsequent to sensory impairment of the trigeminal nerve [4]. Weintaub in 1982 , based on his review of 63 cases of trigeminal trophic syndrome, summarized various aetiologies linked to this condition (trigeminal rhizotomy (46\%), alcohol injection of gasserian ganglion (29\%)) and less frequent causes which include vertebrobasilar insufficiency $(9 \%)$, acoustic neuroma (5\%), post-encephalitic parkinsonism (5\%), syringobulbia (2\%) and unknown (5\%) [5].

Trigeminal trophic syndrome is characterized by a unilateral, frequently crescent-shaped neurotrophic ulceration in the trigeminal dermatome but in majority of the cases the ala nasi, adjacent cheek and lip are affected [6]. The ala nasi corresponding to the nasal area which lacks cartilage may be completely destroyed [7].

\section{OBJECTIVE}

We report the case of a geriatric patient with painless facial and scalp ulceration which turned out to be trigeminal trophic syndrome following herpes zoster. Existing literature on this rare entity is also reviewed.

\section{WPROWADZENIE}

Pierwszy opis zespołu troficznego nerwu trójdzielnego pochodzi z 1901 r., kiedy niemiecki neurolog Wallenberg [1] opisał nadżerkę znajdującą się na skrzydełkach nosa, a następnie zespół Wallenberga. W późniejszym okresie w literaturze anglojęzycznej o zespole tym pisali niezależnie Lovemen [2] i Mckenzie [3] w 1933 r. Zespół troficzny nerwu trójdzielnego był wcześniej znany jako owrzodzenie półksiężycowate ze względu na charakterystyczny kształt zajętej części skrzydełka nosa.

Zespół troficzny nerwu trójdzielnego jest rzadką chorobą, która może pojawić się w wyniku zaburzeń czucia nerwu trójdzielnego [4]. W 1982 r. Weintaub na podstawie opisów 63 przypadków zespołu troficznego nerwu trójdzielnego podsumował możliwe etiologie tej choroby (rizotomia nerwu trójdzielnego (46\%), iniekcje z alkoholu do zwoju trójdzielnego $(29 \%))$, a także rzadsze przyczyny, które obejmują: niewydolność kręgowo-podstawną (9\%), nerwiaka nerwu słuchowego (5\%), parkinsonizm występujący po zapaleniu mózgu (5\%), jamistość opuszki (2\%) oraz idiopatyczne, nieznane (5\%) [5].

Zespół troficzny nerwu trójdzielnego charakteryzuje się jednostronnym, często o kształcie półksiężyca, neurotroficznym owrzodzeniem dermatomów nerwu trójdzielnego, które w większości przypadków dotyczy skrzydełek nosa, przyległego policzka lub wargi [6]. Skrzydełko nosa, odpowiadające części nosowej pozbawionej chrząstki, może zostać całkowicie zniszczone [7].

\section{CEL PRACY}

Opis przypadku pacjenta w starszym wieku z niebolesnym owrzodzeniem twarzy i skóry głowy, które zostało ostatecznie zdiagnozowane jako zespół tro- 


\section{CASE REPORT}

A 72-year-old man came to the outpatient clinic with a 3-month history of progressive, persistent, painless unilateral facial and scalp ulceration. The patient gave a history suggestive of herpes zoster 6 months earlier following which he had developed intense pruritis and a pricking sensation in the affected area. The patient admitted to regularly picking, rubbing and scratching the area for relief. There was no history of any associated systemic ailment like diabetes mellitus, coronary artery disease or hypertension. The patient had many consultations with general physicians before coming to us and had received multiple courses of antibiotics without any improvement.

The general physical examination was within the normal limits. The cutaneous examination revealed a unilateral sharply demarcated deep ulcer involving the left cheek and extending onto the bridge of the nose, upper lip, temple, forehead and scalp approximating the innervation boundaries of ophthalmic (V1) and maxillary divisions (V2) of the trigeminal nerve. The ala nasi was completely destroyed with sparing of the tip of the nose. There was also the presence of areas of depigmentation in the same dermatomal distribution due to post inflammatory changes following herpes zoster (fig. $1 \mathrm{~A}, \mathrm{~B}$ ). There was no regional lymphadenopathy.

Tzanck smear from the ulcer was negative for acantholytic or multinucleated giant cells. Biopsy from the ulcer margin ruled out the possibilities of malignancy, infections and any granulomatous

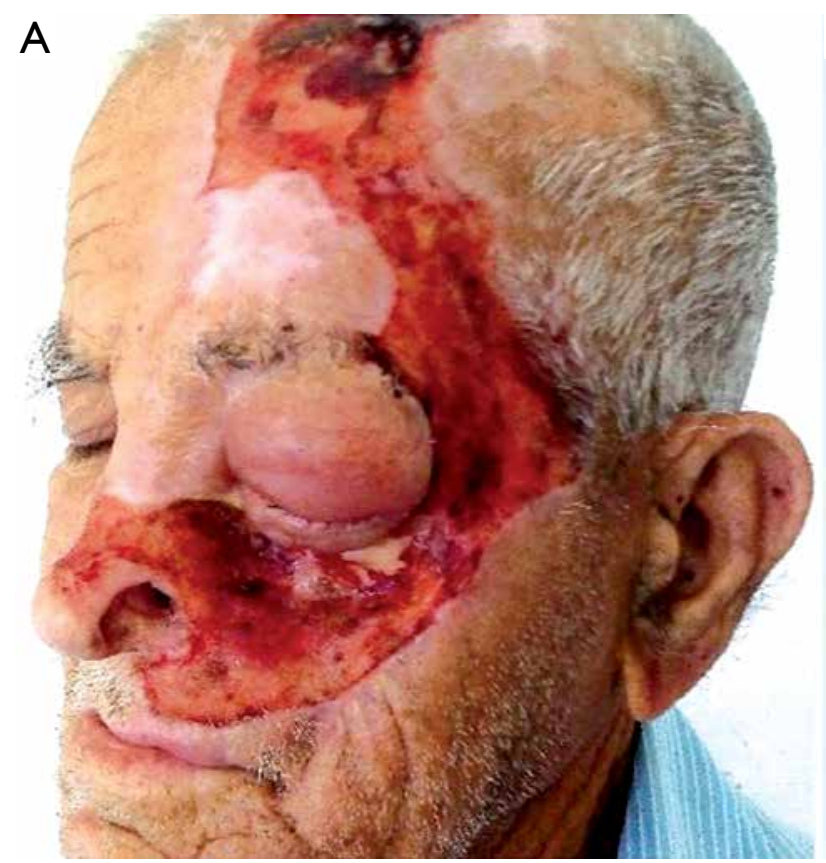

ficzny nerwu trójdzielnego po przebytym półpaścu. Dokonano również przeglądu istniejącego piśmiennictwa dotyczącego tego rzadkiego schorzenia.

\section{OPIS PRZYPADKU}

Mężczyzna 72-letni zgłosił się do Kliniki z powodu postępującego, przewlekłego i niebolesnego owrzodzenia twarzy i skóry głowy, które występowało od 3 miesięcy. W wywiadzie pacjent podawał objawy sugerujące półpaśca 6 miesięcy wcześniej z następczym świądem i uczuciem mrowienia skóry. Pacjent przyznał, że regularnie dotyka, pociera i drapie tę okolicę skóry. W wywiadzie nie stwierdzono towarzyszących chorób przewlekłych, takich jak cukrzyca, choroba niedokrwienna serca i nadciśnienie tętnicze. Przed zgłoszeniem się do kliniki pacjent był konsultowany przez lekarzy pierwszego kontaktu, a wdrożone terapie antybiotykowe nie przyniosły poprawy.

W ogólnym badaniu przedmiotowym nie wykazano odchyleń. Na skórze stwierdzono jednostronne, wyraźnie odgraniczone, głębokie owrzodzenie zlokalizowane na lewym policzku, grzbiecie nosa, górnej wardze, skroni, czole i skórze głowy, graniczące z obszarami unerwienia skóry przez nerw oczny (V1) i szczękowy (V2). Skrzydełko nosa było całkowicie zniszczone, poza koniuszkiem nosa. Obecne były również odbarwienia pozapalne $\mathrm{w}$ miejscach po przebytym półpaścu (ryc. 1 A, B). Nie obserwowano powiększenia okolicznych węzłów chłonnych.

Wynik testu cytologicznego Tzancka w kierunku komórek akantolitycznych lub wielojądrowych komó-

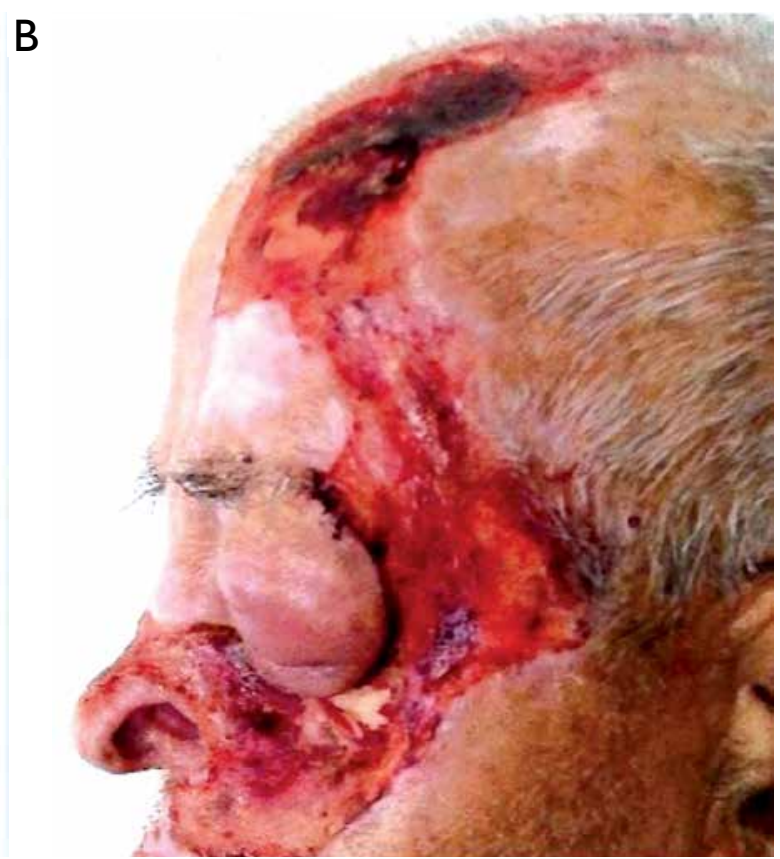

Figure I A, B. Extensive unilateral ulceration involving the nose, cheek, temple and scalp with the destruction of ala nasi

Rycina I A, B. Rozległe, jednostronne owrzodzenie obejmujące nos, policzek, skroń i skórę głowy oraz zniszczone skrzydełko nosa 
condition. Tissue cultures for bacteria, fungus, and atypical mycobacteria were negative. Antinuclear, antineutrophil cytoplasmic antibodies and hepatitis B and C, were negative. Tests for HIV and syphilis were nonreactive. Blood glucose, renal, and liver function tests were within the normal range. Considering the patient's history of herpes zoster and paraesthesias in the same dermatomal distribution, a diagnosis of trigeminal trophic syndrome due to herpes zoster was made. An ophthalmological evaluation for periorbital edema of the left eye revealed the presence of corneal ulceration.

The patient was put on gabapentine (300 mg three times daily) along with an occlusive dressing of the ulcer with a topical antibiotic and was also advised to trim his nails and wear gloves to avoid further trauma. During the 1-week hospital stay, the patient improved symptomatically and was advised reconstructive surgery which he refused and was lost to follow up thereafter.

\section{DISCUSSION}

Trigeminal trophic syndrome is known by various other names in medical literature such as 'trigeminal neurotrophic ulceration' or 'trigeminal neuropathy with ulceration', 'trophic ulceration of ala nasi' and 'ulceration en arc' [6]. It is an uncommon disorder in which trophic ulceration follows minor repetitive trauma to anaesthetic skin within the trigeminal area. Neurotrophic changes in the trigeminal area may follow the destruction of fibres conveying pain and temperature sensations. Causes of this disorder include central sensory neuronal damage, or damage to the trigeminal nerve by attempts to relieve intractable trigeminal neuralgia by surgery or alcohol injection in the gasserian ganglion or herpes zoster-related neuritis [8].

The time lag from trigeminal nerve injury to ulceration may range from weeks to decades. There is a female preponderance of $2: 1$ or more and the disorder usually appears after the age of 50 years [9]. In another case series of 14 trigeminal trophic syndrome patients, Garza reported female to male ratio of $6: 1$ with the mean age of onset 45 years [10]. The onset of disease in our patient was much later in the seventh decade. Paediatric cases are extremely rare with only a few reports of post-herpetic trigeminal trophic syndrome [11, 12].

The clinical appearance of trigeminal trophic syndrome is distinctive, starting as an erosion or crust and enlarging into a crescent-shaped ulcer which may extend to involve the cheek and upper lip destroying the ala nasi but sparing the nasal tip because of its innervation by the ethmoidal branch of the ophthalmic division of the trigeminal nerve rek olbrzymich z wymazu pobranego z dna wrzodu był ujemny. W badaniu histopatologicznym wykluczono choroby nowotworowe, zakaźne i ziarniniakowe. Posiew z materiału tkankowego w kierunku bakterii, grzybów i atypowych prątków był ujemny. Przeciwciała przeciwjądrowe i przeciwko cytoplazmie neutrofilów oraz markery wirusowego zapalenia wątroby typu B i C były ujemne. Wyniki badań na obecność HIV i kiły były negatywne. Stężenie glukozy we krwi oraz badania czynnościowe wątroby i nerek były w normie. Na podstawie obrazu klinicznego i wywiadu (przebyty półpasiec i parestezje) rozpoznano zespół troficzny nerwu trójdzielnego po przebytym półpaścu. W badaniu okulistycznym wykonanym $\mathrm{z}$ powodu okołooczodołowego obrzęku lewego oka wykazano owrzodzenie rogówki.

Pacjentowi podano gabapentynę (300 mg 3 razy dziennie) i założono opatrunek okluzyjny z miejscowym antybiotykiem. Zalecono, by pacjent skrócił paznokcie i nosił rękawiczki w celu uniknięcia dalszych urazów. W trakcie pierwszego tygodnia hospitalizacji objawy uległy poprawie i pacjentowi zaproponowano operację rekonstrukcyjną. Pacjent odmówił poddania się zabiegowi, a także nie stawiał się na dalsze wizyty kontrolne.

\section{OMÓWIENIE}

Zespół troficzny nerwu trójdzielnego jest znany w piśmiennictwie medycznym pod różnymi nazwami: neurotroficzne owrzodzenie nerwu trójdzielnego, neuropatia nerwu trójdzielnego z owrzodzeniami, troficzne owrzodzenie skrzydełek nosa oraz owrzodzenie półksiężycowate [6]. Jest to rzadka choroba, w której niewielki, powtarzający się uraz pozbawionej czucia skóry z obszaru unerwienia nerwu trójdzielnego prowadzi do troficznego owrzodzenia. Zmiany neurotroficzne w obszarze trójdzielnym mogą wystąpić wskutek zniszczenia włókien przewodzących czucie bólu i temperatury. Przyczyny choroby obejmują uszkodzenie ośrodkowe neuronów związanych z czuciem lub uszkodzenie nerwu trójdzielnego podczas leczenia opornej na terapię neuralgii trójdzielnej poprzez zabiegi chirurgiczne lub iniekcje alkoholowe stosowane do zwoju trójdzielnego albo przy zapaleniu nerwu związanego z półpaścem [8].

Okres od urazu nerwu trójdzielnego do wystąpienia owrzodzenia wynosi od tygodnia do kilkudziesięciu lat. Przewaga zachorowalności kobiet wynosi $2: 1$ lub więcej, a choroba pojawia się zazwyczaj w 50 . roku życia [9]. W innych badaniach obejmujących 14 pacjentów z zespołem troficznym nerwu trójdzielnego Garza stwierdził, że stosunek kobiet do mężczyzn wynosił $6: 1$, a średni wiek wystąpienia choroby 45 lat [10]. W przedstawionym przypadku pacjent zachorował zdecydowanie później - w wieku powyżej 70 lat. Zachorowania wśród dzieci są niezwykle rzad- 
$[13,14]$. Involvement of other areas like the scalp, forehead, temple, jaw and ear is uncommon [6]. In our patient, the ulcer was deep and extensive, and the temporal region, forehead and scalp were involved which is very rarely reported in the literature.

Trigeminal trophic syndrome may be misdiagnosed as malignancy, infections (bacterial, fungal, viral, protozoal), vasculitis (Wegener's granulamatosis), etc. Among neoplasms, trigeminal trophic syndrome may closely resemble basal cell carcinoma and epidermoid carcinoma [7]. Trigeminal trophic syndrome may also closely mimic factitial ulcers but the sensory loss seen in trigeminal trophic syndrome will not be a feature in factitial dermatitis [6] However, the typical history and clinical presentation often help to clinch the diagnosis. Histology is non-diagnostic as there are no specific histological findings. It is useful only to rule out other causes of facial ulceration [15].

Management of trigeminal trophic syndrome is challenging and calls for a multidisciplinary approach. The cornerstone of treatment is counselling the patient about the role of self-mutilation in the causation of the condition [11]. The wound should be protected with occlusive dressings and the use of gloves by the patient should be emphasized to prevent further trauma and promote healing. Drugs reported to be effective include vitamin B supplementation, diazepam, amitriptyline, chlorpromazine, carbamazepine, acyclovir, intralesional triamcinolone acetonide [6]. Other treatment options that have been used include radiation, transcutaneous electrical neural stimulation, iontophoresis and nerve blockade, ipsilateral cervical sympathectomy, stellate ganglionectomy, and surgical reconstruction of the ulceration [14].

Trigeminal trophic syndrome subsequent to herpes zoster was first reported by Litschel et al. [16]. Since then only a few sporadic post-herpetic cases of trigeminal trophic syndrome have appeared in the literature.

The case reported herein is unique in the following ways:

- late occurrence of the disease in the seventh decade in a male,

- extensive and deep ulcer involving sites known to be uncommonly involved,

- delayed diagnosis and incorrect treatment leading to progression of the disease prolonging the morbidity and hence the psychological trauma.

The present case also emphasizes the importance of regular follow up of patients who suffer from herpes zoster and consequently develop post-herpetic neuralgia, especially in geriatric patients. kie, tylko opisano zespół troficzny nerwu trójdzielnego po przebytym półpaścu [11, 12].

Objawy kliniczne zespołu troficznego nerwu trójdzielnego są charakterystyczne: początkowo jest to nadżerka lub strup, które powiększają się do półksiężycowatego owrzodzenia, później może ono zająć policzek i górną wargę, niszcząc skrzydełko nosa, ale oszczędzając koniuszek nosa, z powodu unerwienia przez gałąź sitową nerwu ocznego odchodzącego od nerwu trójdzielnego [13, 14]. Zajęcie innych obszarów, takich jak skóra głowy, czoło, skroń, żuchwa lub ucho, występuje rzadko [6]. U przedstawionego pacjenta owrzodzenie było głębokie i rozległe, z zajęciem okolicy skroniowej, czołowej oraz owłosionej skóry głowy, co jest niezwykle rzadko opisywane w piśmiennictwie.

Zespół troficzny nerwu trójdzielnego może być błędnie rozpoznawany jako: nowotwór, infekcja (bakteryjna, grzybicza, wirusowa, pierwotniakowa), zapalenie naczyń (ziarniniakowatość Wegenera) itd. Zespół troficzny nerwu trójdzielnego może również bardzo przypominać podstawnokomórkowego i płaskonabłonkowego raka skóry [7]. Choroba może też wyglądać jak wywołany wrzód, w którym jednak nie stwierdza się utraty czucia występującej $\mathrm{w}$ zespole troficznym nerwu trójdzielnego [6]. Typowy wywiad i objawy kliniczne często przesądzają o rozpoznaniu. Badanie histopatologiczne jest niediagnostyczne. Badanie pozwala jednak wykluczyć inne przyczyny owrzodzenia twarzy [15].

Postępowanie w przypadku zespołu troficznego nerwu trójdzielnego jest trudne i wymaga podejścia wielodyscyplinarnego. Najważniejszą częścią leczenia jest poinformowanie pacjenta o roli samookaleczania jako przyczyny choroby [11]. Rana powinna być chroniona przez opatrunek okluzyjny, a pacjent powinien zakładać rękawiczki w celu ochrony rany przed dalszymi urazami i przyspieszenia gojenia. Do skutecznych leków należą: suplementy z witaminą B, diazepam, amitryptylina, chlorpromazyna, karbamazepina, acyklowir i acetonid triamcynolonu podawany doogniskowo [6]. Inne wykorzystywane metody terapeutyczne to: radioterapia, przezskórna elektryczna stymulacja nerwów, jonoforeza i blokowanie nerwów, ipsilateralna sympatektomia szyjna, wycięcie splotu gwiaździstego oraz chirurgiczna rekonstrukcja owrzodzenia [14].

Zespół troficzny nerwu trójdzielnego po przebytym półpaścu został po raz pierwszy opisany przez Litschela i wsp. [16]. Podobne opisy przypadków rzadko występują w piśmiennictwie.

Opisywany przypadek jest wyjątkowy pod kilkoma względami:

- choroba pojawiła się późno - po 70. roku życia,

- rozległe i głębokie owrzodzenie objęło rzadko zajmowane miejsca,

- opóźnione rozpoznanie i nieprawidłowy schemat leczenia przyczyniły się do rozwoju choroby, co 


\section{CONCLUSIONS}

This case highlights a rare but important clinical entity that may be misdiagnosed. Awareness about this unusual occurrence and a high index of suspicion among physicians in general and specialists, in particular, will not only reduce the odds of misdiagnosis but will also save the patient from undue, prolonged and ineffective treatments.

\section{CONFLICT OF INTEREST}

The authors declare no conflict of interest. zwiększyło liczbę powikłań i spowodowało uraz psychologiczny u pacjenta.

Przedstawiony przypadek podkreśla również znaczenie regularnych wizyt kontrolnych pacjentów z neuralgią popółpaścową. Dotyczy to zwłaszcza pacjentów w starszym wieku.

\section{WNIOSKI}

Powyższy przypadek przedstawiono ze względu na rzadką, lecz klinicznie ważną chorobę, która może zostać błędnie rozpoznana. Świadomość występowania tej choroby wśród lekarzy, szczególnie specjalistów, może zmniejszyć liczbę błędnych rozpoznań i zaoszczędzić pacjentowi niewłaściwego, wydłużonego i nieskutecznego leczenia.

\section{KONFLIKT INTERESÓW}

Autorzy nie zgłaszają konfliktu interesów.

\section{References}

\section{Piśmiennictwo}

1. Wallenberg A.: Klinische Beitrage zur Diagnostik acuter Herderkrankungen des Verlangerten Marks und der Bruke. Dt Z Nervenheeilk 1901, 19, 227-231.

2. Loveman A.B.: An unusual dermatosis following section of the fifth cranial nerve. Arch Dermatol Syph 1933, 28, 369-375.

3. McKenzie K.G.: Observations on the results on the operative treatment of trigeminal neuralgia. Can Med Assoc 1933, 29, 492-496.

4. Luksić I., Luksić I., Sestan-Crnek S., Virag M., Macan D.: Trigeminal trophic syndrome of all three nerve branches: an underrecognized complication after brain surgery. J Neurosurg 2008, 108, 170-173.

5. Weintraub E., Soltani K., Hekmatpanah J., Lorincz A.L.: Trigeminal trophic syndrome. A case and review. J Am Acad Dermatol 1982, 6, 52-57.

6. Sadeghi P., Papay F.A., Vidimos A.T.: Trigeminal trophic syndrome - report of four cases and review of the literature. Dermatol Surg 2004, 30, 807-812.

7. Demir Y., Aktepe F., Özçukurlu A.: Trigeminal trophic syndrome: a case with alar ulceration. Eur J Plast Surg 2002, 25, 38-40.

8. Archer C.B., Eddy D.J.: The skin and the nervous system. [In:] Rook's Textbook of Dermatology. T. Burns, S. Breathnach, N. Cox, C. Griffiths (eds.), Wiley-Blackwell Ltd., Oxford, 2010, 63.1-63.25.

9. Goodnight J.W., Calcaterra T.: Trigeminal trophic syndrome: a report of two cases and review. Am J Otolaryngol 1994, 15, 219-222.

10. Garza I.: The trigeminal trophic syndrome: an unusual cause of face pain, dysaesthesias, anaesthesia and skin/soft tissue lesions. Cephalalgia 2008, 28, 980-985.

11. Kautz O., Bruckner-Tuderman L., Müller M.L., Schempp C.M.: Trigeminal trophic syndrome with extensive ulceration following herpes zoster. Eur J Dermatol 2009, 19, 61-63.

12. Dhawan A.K., Bisherwal K., Grover C.: Post herpes zoster trigeminal trophic syndrome in a child. Indian J Dermatol Venereol Leprol 2015, 60, 414-415.

13. Rashid R.M., Khachemoune A.: Trigeminal trophic syndrome. J Eur Acad Dermatol Venereol 2007, $21,725-731$.

14. Lane J.E., Deliduka S.: Self-induced nasal ulceration from trigeminal trophic syndrome. Cutis 2008, 81, 419-420.

15. Sawada T., Asai J., Nomiyama T., Masuda K., Takenaka H., Katoh N.: Trigeminal trophic syndrome: report of a case and review of the published work. J Dermatol 2014, 41, 525-528.

16. Litschel R., Winkler H., Dazert S., Sudhoff H.: Herpes zoster-associated trigeminal trophic syndrome: a case report and review. Eur Arch Otorhinolaryngol 2003, 260, 86-90.

Received: 24.10 .2017

Accepted: 29.01.2018

Otrzymano: $24.10 .2017 \mathrm{r}$.

Zaakceptowano: 29.01.2018 r.

How to cite this article

Kaul P., Mushtaq S., Kalsotra P.: Trigeminal trophic syndrome associated with post-herpetic neuralgia - report of a rare case with review of literature. Dermatol Rev/Przegl Dermatol 2018, 105, 542-547. DOI: https://doi.org/10.5114/dr.2018.78075. 